\title{
Breastfeeding assessment protocols and Speech Therapy: an integrative literature review
}

\author{
Franciani Bairros Nobre de Oliveira ${ }^{1}$ \\ https://orcid.org/0000-0003-4269-5333 \\ Carolina Pereira Fernandes ${ }^{1}$ \\ https://orcid.org/0000-0001-9555-6631 \\ Léia Gonçalves Gurgel ${ }^{1,2}$ \\ https://orcid.org/0000-0003-2679-1798 \\ Cristina Ide Fujinaga ${ }^{3}$ \\ https://orcid.org/0000-0003-0852-1567 \\ Sheila Tamanini de Almeida ${ }^{1}$ \\ https://orcid.org/0000-0002-2824-4336
}

Universidade Federal de Ciências da Saúde de Porto Alegre - UFCSPA, Curso de Fonoaudiologia, Porto Alegre, Rio Grande do Sul, Brasil.

Universidade Federal de Ciências da Saúde de Porto Alegre - UFCSPA, Laboratório de Pesquisa em Avaliação Psicológica, Porto Alegre, Rio Grande do Sul, Brasil.

Universidade Estadual do Centro-0este, Curso de Fonoaudiologia, Irati, Paraná, Brasil.

This research was conducted at Universidade Federal de Ciências da Saúde de Porto Alegre, Porto Alegre, RS, Brazil.

Conflict of interests: Nonexistent

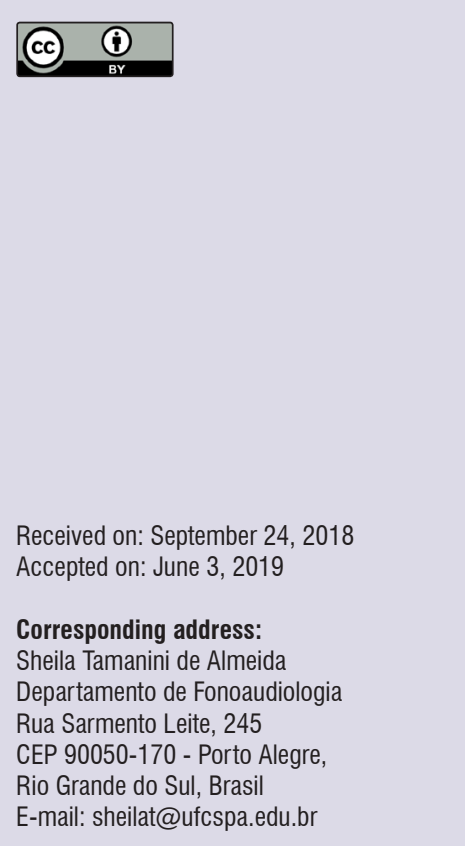

\section{ABSTRACT}

Objective: to investigate protocols used by Speech Therapists to evaluate breastfeeding.

Methods: this is an integrative literature review that aims to synthesize available evidence on the evaluation of breastfeeding, from 2002 to 2015. The inclusion criteria were scientific articles that approached breastfeeding evaluation performed by Speech Therapists, published in English and Portuguese. Papers that did not present summaries in their entirety were discarded.

Results: a total of 140 studies were found, 134 being excluded. The remaining six publications evaluated breastfeeding and were included in the study with four instruments. The articles selected aimed at evaluating the mothers' knowledge about breastfeeding and its relation to language, the first feeding of the premature baby, describing the initial conditions of breastfeeding, relating breastfeeding to the cup/bottle supply and evaluating orofacial characteristics and breastfeeding. The protocols evaluated aspects of the infant's state of consciousness, behavior and positioning, mother's breastfeeding behavior, breast characteristics, latching and milking, and conditions after breastfeeding.

Conclusion: there are few studies in Speech Therapy that use standardized and validated protocols for breastfeeding evaluation. The major focus is on the evaluation of preterm infants. It is suggested that new studies be performed, especially with a focus on validating instruments.

Keywords: Breast Feeding; Speech Therapy, Language and Hearing Sciences; Protocols; Sucking Behavior 


\section{INTRODUCTION}

Currently, breastfeeding has been the subject of research because of the growing evidence of the importance of this practice; it is considered as a promoter of the physical, mental and psychological health of the child and the woman who breastfeeds, as well as preventing infant deaths ${ }^{1}$. Evidence is growing every year that breastfeeding is the best way to feed the child. Exclusive maternal breastfeeding (EMB) is recommended in the first six months of the child's life exclusively, and should be maintained up to two years-old or older in a complementary way $^{2,3}$. Breastfeeding promotes craniofacial development of the baby by appropriate movements of the orofacial muscles, this because the tactile receptors of the baby's lips detect the nipple and take the labial muscles to contract around the nipple-areola complex, featuring a hermetical sealing ${ }^{2,3}$. The nipple is the first to be compressed between the upper gingival border and the tip of the tongue, covering the lower gingival border with a depression of the mandible and tongue, which requires the working of the lingual muscles. Concomitantly to these events, mandibular movement occurs, at which time suction is exerted by a decrease in intraoral pressure, which becomes negative ${ }^{2,3}$. In suction, the tongue presents rhythmic ripples on its surface, anterior to posterior ${ }^{2,3}$ forming a cycle of suction, respiration, and swallowing. Some of the skills taken into consideration during the evaluation of preparedness and newborn nursing to breastfeeding are related to sucking, lip position during breastfeeding at the breast, the nipple arrest, among others aspects ${ }^{4}$.

Taking into consideration the fact that counseling in EMB is essential to avoid early weaning, it is possible to reinforce the importance of inclusion of the speech therapist in multidisciplinary teams contributing to successful maternal breastfeeding $(\mathrm{MB})^{5,6}$. The role of speech therapy in the care of the newborn has the role of evaluating and encouraging breastfeeding in order to develop phonoarticulatory organs and favoring the mother-child relationship ${ }^{7}$. In order for breastfeeding to be successful, several factors related to the newborn and the puerperal need to be adjusted, so it is essential that the mother receive the necessary guidelines to feel safe when breastfeeding ${ }^{5}$. Maternal inexperience and lack of information may be one of the causes of early weaning ${ }^{6}$.

Despite the multidisciplinary efforts, programs and public policies encouraging $\mathrm{MB}$, early onset rates, duration and exclusivity do not include the desirable levels of prevalence, since, according to the WHO, the rate should be from $90 \%$ to $100 \%{ }^{8}$. One of the factors responsible for early weaning is associated with management difficulties presented during the breastfeeding process ${ }^{9}$. In this context, one of the strategies for assessing child care in Brazil is the monitoring of the prevalence of breastfeeding, due to its role in reducing infant morbidity and mortality, making the initiatives for promotion, protection and support to breastfeeding priority by the National Health Policy of the Child ${ }^{8}$.

Speech Therapy operates at all levels of health care, with actions to promote, protect and recover health. The speech-language pathologist's activities related to breastfeeding include guidelines for mothers, identification of inappropriate oral habits of the baby and speech-language therapy ${ }^{10}$. Thus, for an adequate intervention, it is necessary to understand how breastfeeding is characterized and the quality of breastfeeding, especially with the appropriate evaluation and use of validated and standardized instruments, built specifically for this purpose ${ }^{11}$.

The assessment of breastfeeding has the UNICEF-approved protocol "UNICEF's Breastfeeding Observation Protocol" ${ }^{8}$. This protocol is composed of five categories of favorable behavior and difficulties indicative. These categories can be classified qualitatively, in: good, fair and poor. This evaluation is considered a gold standard for the verification of the performance of the mother/baby dyad at the time of breastfeeding $^{8}$. However, in the protocol, there is no specific evaluation regarding the suckling pattern of the newborn, and knowing specific issues of the baby's oral behavior becomes relevant to the management of breastfeeding, with special emphasis on its initial phase.

In this context, the present review is justified by the importance of the knowledge and the approach that the speech therapist should have to evaluate breastfeeding in its initial phase, as a strategy to promote breastfeeding and prevent changes in this practice and early weaning. Therefore, this study aims to investigate the protocols used by Speech-Language Pathology to evaluate breastfeeding of the newborn, describing the aspects considered for such evaluations.

\section{METHODS}

The present study is an integrative review of the literature, with the purpose of synthesizing the scientific knowledge on the subject, allowing evidence of the state of the art, and the main data available in 
the literature. It is intended to contribute to the development of knowledge in the area of speech-language assessment of breastfeeding. The method of the present study presents six phases for the elaboration of the research: elaboration of the guiding question, search or sampling in the literature, data collection, critical analysis of included studies, discussion of the results, and presentation of the integrative review ${ }^{12}$. Two questions guided the writing of the present study: 1) What are the protocols used by Speech-Language Pathology and Audiology to evaluate breastfeeding in the newborn? And 2) What are the aspects taken into account in such evaluations?
The search for the articles was carried out with the following Descriptors, in English and Portuguese: Breast Feeding, breastfeeding and speech therapy, Speech Therapy and its synonyms: Breast Feeding Exclusive; Breastfeeding; Breastfeeding Exclusive; Exclusive Breast Feeding; Exclusive Breastfeeding; Feeding Breast; Breastfeeding; Therapy Speech; Speech Therapies and Therapies Speech. The following databases were consulted: LILACS, MEDLINE via PubMed, Scopus; and SCiELO. The descriptors and their terms were combined using Boolean operators (Figure 1).

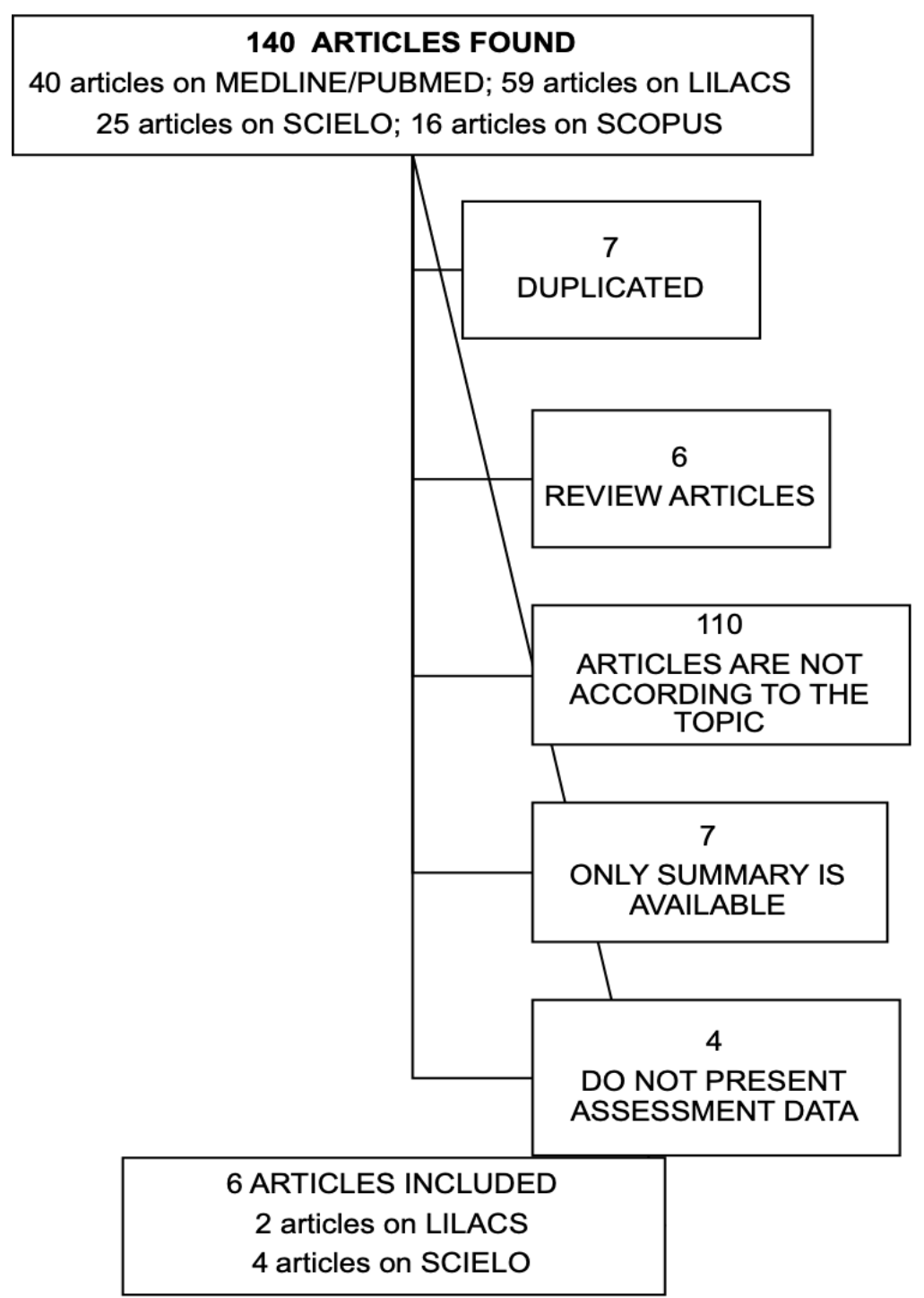

Figure 1. Results of the Integrative Review according to the databases: LILACS, MEDLINE via PubMed, Scopus, and SCiELO 
Among the inclusion criteria, we considered the scientific articles indexed in databases that addressed the evaluation of breastfeeding performed by speech therapists, published in the English and Portuguese languages. As exclusion criteria, papers that do not present full abstracts in the databases and in the library were excluded. The titles and abstracts of all studies resulting from database searches were initially read by two previously trained researchers. The previously selected studies have moved on to the reading phase of the full text. For this, standardized forms previously constructed for the present revision were used. At the end, productions meeting the established eligibility criteria were included.

Following the reading of the selected researches in full, we continued with the analysis and organization of the topics: instruments used in Speech-Language Pathology and Audiology to evaluate the MB and the evaluation/punctuation methods used in each one, with the identification of the aspects evaluated by each protocol applied by the speech therapy.

\section{LITERATURE REVIEW}

From the integrative review, six publications were selected, being possible to identify four instruments of evaluation of the MB. Table 1 describes and classifies the results, evidencing the knowledge produced on the proposed theme, with the following items: authors, journal, year of publication, design, objective and sample of the articles.

Table 1. Distribution of the publications of the integrative review, according to authors, journal, year of publication, delimitation, objective and sample

\begin{tabular}{|c|c|c|c|c|}
\hline AUTHORS & JOURNAL & DELIMITATION & OBJECTIVE & SAMPLE \\
\hline $\begin{array}{l}\text { Delgado, Zorzetto, } \\
2002 .\end{array}$ & $\begin{array}{l}\text { Revista Brasileira } \\
\text { Crescimento e } \\
\text { Desenvolvimento } \\
\text { Humano São Paulo }\end{array}$ & $\begin{array}{l}\text { Observational study; } \\
\text { descriptive; cross-sectional; } \\
\text { group; prospective and } \\
\text { contemporary. }\end{array}$ & $\begin{array}{l}\text { To verify the knowledge that mothers of } \\
\text { preterm children have about breastfeeding } \\
\text { and the importance of breastfeeding as a form } \\
\text { of communication, describing the signs of } \\
\text { bonding and communicative behaviors of the } \\
\text { mother-baby dyad during breastfeeding. }\end{array}$ & $\begin{array}{l}15 \text { mother/RNPT } \\
\text { binomials. }\end{array}$ \\
\hline $\begin{array}{l}\text { Castelli, Almeida, } \\
\quad 2015 .\end{array}$ & Revista CEFAC & $\begin{array}{l}\text { Cross-sectional, quantitative } \\
\text { and descriptive study. }\end{array}$ & $\begin{array}{l}\text { To evaluate the orofacial characteristics and } \\
\text { breastfeeding of preterm infants before hospital } \\
\text { discharge and to verify possible relationships } \\
\text { between the orofacial motor sensory system } \\
\text { and breastfeeding. }\end{array}$ & 20 RNPT. \\
\hline $\begin{array}{l}\text { Silva, Almeida, } \\
2015 .\end{array}$ & Revista CEFAC & $\begin{array}{c}\text { Cross-sectional } \\
\text { observational study. }\end{array}$ & $\begin{array}{l}\text { To evaluate preterm newborns during the first } \\
\text { maternal breast offer in a neonatal intensive } \\
\text { care unit. }\end{array}$ & 15 RNPT. \\
\hline $\begin{array}{l}\text { Mosele, Santos, } \\
\text { Godói, Costa, De } \\
\text { Toni, Fujinaga, } \\
2014 . \\
\end{array}$ & Revista CEFAC & Diagnostic study. & $\begin{array}{l}\text { To test the accuracy of the "Instrument for the } \\
\text { newborn sucking at breastfeeding maternal". }\end{array}$ & $\begin{array}{l}152 \text { mother/ } \\
\text { term newborns } \\
\text { binomials. }\end{array}$ \\
\hline $\begin{array}{l}\text { Scheeren, } \\
\text { Mengue, } \\
\text { Devincenzi, } \\
\text { Barbosa, Gomes, } \\
2012 . \\
\end{array}$ & $\begin{array}{l}\text { Jornal da Sociedade } \\
\text { Brasileira de } \\
\text { Fonoaudiologia }\end{array}$ & $\begin{array}{l}\text { observational, prospective } \\
\text { and not compared, cross- } \\
\text { sectional. }\end{array}$ & $\begin{array}{l}\text { To describe the initial conditions of } \\
\text { breastfeeding of preterm infants. }\end{array}$ & $\begin{array}{l}26 \text { mother/baby } \\
\text { binomials. }\end{array}$ \\
\hline $\begin{array}{c}\text { Medeiros, } \\
\text { Bernardi, } 2011 .\end{array}$ & $\begin{array}{l}\text { Revista Sociedade } \\
\text { Brasileira de } \\
\text { Fonoaudiologia }\end{array}$ & It is not included. & $\begin{array}{l}\text { To verify the offer of maternal breast in infants } \\
\text { born preterm, hospitalized in the Intensive Care } \\
\text { Unit, relating this data to the way of offering } \\
\text { the diet (cup or bottle), in the absence of the } \\
\text { mother, and the speech-language stimulation } \\
\text { performed. }\end{array}$ & 48 RNPT. \\
\hline
\end{tabular}

Subtitle: RNPT: recém-nascido prematuro (premature newborn) 
During the analysis of the studies included in this review, there were four protocols used by the authors: "Protocol of Observation of Signs of Mother/Baby Link and Communication During Breastfeeding" 7, "Protocol for Assessment and Speech-Language Pathology" 13, "Breastfeeding Evaluation in Premature Newborns", also called "Adapted Bono-Speech-Language Pathology Assessment Form" 5,14, "UNICEF Briefing and Evaluation Protocol" 6,15. In the identified protocols, the following items were evaluated: Consciousness, hand and milking conditions, physical contact, communication between the mother and the baby, including signs of bonding and affective ties, visual contact, also the comfort of the mother, how to insure the breast and position of the NB, characteristics, anatomy and appearance of the breast, signs of engorgement, trauma and pain, NB behavior after breastfeeding, identification of NB needs, body posture), final conditions of the feeding (the way the mother removes the baby from the breast and conditions of the nipple), signs of milk ejection. To facilitate the presentation, a table was drawn up with the presentation of the instruments, according to evaluated items and method of punctuation (Table 2).

Table 2. Distribution of the protocols found in the integrative review, according to evaluated items and scoring methods

\begin{tabular}{|c|c|c|c|c|}
\hline $\begin{array}{l}\text { EVALUATION } \\
\text { INSTRUMENT }\end{array}$ & $\begin{array}{l}\text { TYPE OF } \\
\text { EVALUATION }\end{array}$ & ASSESSED ITEMS & $\begin{array}{l}\text { SCORING } \\
\text { METHOD }\end{array}$ & $\begin{array}{l}\text { ADAPTED } \\
\text { INSTRUMENT } \\
\end{array}$ \\
\hline $\begin{array}{l}\text { Protocol for observation } \\
\text { of signs of mother/ } \\
\text { baby bonding and } \\
\text { communication during } \\
\text { breastfeeding. }\end{array}$ & $\begin{array}{l}\text { Evaluation of } \\
\text { the affective } \\
\text { bond between } \\
\text { mother and } \\
\text { baby during } \\
\text { breastfeeding }\end{array}$ & $\begin{array}{l}\text { Baby awareness level, eye contact during breastfeeding, } \\
\text { physical contact, communication and facial expression } \\
\text { of mother/baby during breastfeeding and identification of } \\
\text { baby's needs. }\end{array}$ & $\begin{array}{l}\text { It does not } \\
\text { score, only } \\
\text { observational. }\end{array}$ & $\begin{array}{l}\text { Adaptation of the } \\
\text { protocol "newborn } \\
\text { screening and } \\
\text { intervention in the } \\
\text { contest of health } \\
\text { care". }\end{array}$ \\
\hline $\begin{array}{l}\text { Protocol for the } \\
\text { evaluation of } \\
\text { breastfeeding of the } \\
\text { preterm newborn/Form } \\
\text { for the Assessment } \\
\text { of Speech-Language } \\
\text { Pathology of } \\
\text { breastfeeding adapted. }\end{array}$ & $\begin{array}{l}\text { Evaluation of } \\
\text { breastfeeding }\end{array}$ & $\begin{array}{l}\text { Seven categories: I. breast-related aspects (anatomy, } \\
\text { ejection signs, engorgement, trauma and pain); II. Reflection } \\
\text { of baby search; III. Signs of mother/newborn bonding (signs } \\
\text { of autonomy, state of consciousness of the newborn, } \\
\text { how to hold the newborn, attention to the newborn's face, } \\
\text { physical touches of the mother in the newborn); IV. position } \\
\text { of mother/newborn during breastfeeding (comfort of the } \\
\text { mother, way of holding the breast, distance between the } \\
\text { hand and the areola, pressure in the lactating ducts, position } \\
\text { of the newborn, head / neck of the newborn, nose of the } \\
\text { newborn); V. conditions of attachment to the breast (chin } \\
\text { of the newborn, mouth, lip sealing, areola); VI. Milking } \\
\text { conditions (jaw movement, cheeks, sucking rhythm, } \\
\text { sucking / deglutition / breathing pattern) and VII. final } \\
\text { conditions of the breastfeeding (mother's way of removing } \\
\text { the newborn from the breast, chest conditions, nipple } \\
\text { conditions, newborn's behavior at the end of the feeding). }\end{array}$ & $\begin{array}{l}\text { Two (2) points } \\
\text { indicate adequate } \\
\text { observed } \\
\text { conditions, that } \\
\text { is, those closest } \\
\text { to the ideal; one } \\
\text { (1) point indicates } \\
\text { intermediate } \\
\text { conditions and } \\
\text { zero (0) indicates } \\
\text { inadequate } \\
\text { conditions. }\end{array}$ & $\begin{array}{l}\text { Adapted from } \\
\text { the "Protocol of } \\
\text { observation of the } \\
\text { feeding of the newborn } \\
\text { to the term". }\end{array}$ \\
\hline $\begin{array}{l}\text { Observation Protocol } \\
\text { and evaluation of the } \\
\text { feeding. }\end{array}$ & $\begin{array}{l}\text { Evaluation of } \\
\text { breastfeeding }\end{array}$ & $\begin{array}{l}\text { Mother/child position; physical contact; responses of the } \\
\text { pair; suction suitability; breast anatomy; and affectivity; } \\
\text { reflection of demand; baby calm and alert; suction (rhythm } \\
\text { and force); position of tongue, lips and cheek; signs of milk } \\
\text { ejection and characteristic of the handle. }\end{array}$ & $\begin{array}{l}\text { Qualitative: good, } \\
\text { fair and poor. }\end{array}$ & $\begin{array}{l}\text { Protocol } \\
\text { recommended by the } \\
\text { UNICEF. }\end{array}$ \\
\hline $\begin{array}{l}\text { Evaluation protocols } \\
\text { and speech-language } \\
\text { pathology. }\end{array}$ & $\begin{array}{l}\text { Evaluation } \\
\text { of feeding in } \\
\text { cup, bottle and } \\
\text { maternal breast }\end{array}$ & $\begin{array}{l}\text { Identification and medical history, type of feeding at the } \\
\text { time of assessment, behavioral status at the beginning of } \\
\text { the breastfeeding, breastfeeding readiness, body posture/ } \\
\text { motor pattern, suction, jaw movement, tongue movement, } \\
\text { swallowing (cup), signs of stress, behavioral status after } \\
\text { breastfeeding, breastfeeding schedules, efficacy (VO): }>3 \\
\text { ml/min, no sign of stress and conduct. }\end{array}$ & $\begin{array}{l}\text { It was not } \\
\text { mentioned in the } \\
\text { article. }\end{array}$ & $\begin{array}{l}\text { Protocol of evaluation } \\
\text { and speech-language } \\
\text { pathology, which was } \\
\text { part of the routine } \\
\text { of the Speech and } \\
\text { language Pathology } \\
\text { team of the Hospital } \\
\text { and Maternity } \\
\text { Neomater, located } \\
\text { in São Bernardo do } \\
\text { Campo (private use). }\end{array}$ \\
\hline
\end{tabular}


The results obtained in this study evidenced the existence of few protocols used by speech therapists to perform the evaluation of breastfeeding in newborns, these onesare only four. Among these protocols, one was validated 6,15 , two were adapted $\mathrm{d}^{5,7,14}$ and one was used exclusively for the application site ${ }^{13}$. Only two studies presented a common method of evaluation ${ }^{5,14}$.

The protocols present in the studies in the present review evaluated breastfeeding in the maternal breast presenting some items in common, and the state of consciousness of the newborn is the most observed characteristic. The state of consciousness indicated for breastfeeding was alert and calm, since the alertness of the baby also interferes in the establishment of affection between mother and child, emphasizing that premature babies are sleepier, which can cause the mother to be disheartened ${ }^{16}$. This item, therefore, in agreement with the specialized literature, is presented as an essential inclusion in the evaluation performed by every professional involved with breastfeeding.

Other items evaluated in the instruments found were the physical contact between the mother and the baby, including aspects related to the positioning of the child and the affectivity observed in the breastfeeding process (in two instruments) ${ }^{7,5,14}$; the demand reflex (in two instruments) 5,6,14,15; and the conditions of the handle and milking (on an instrument) ${ }^{5,14}$. The detailed analysis of the behavior of the newborn after breastfeeding was infrequent in the evaluations, being observed in only one of the protocols ${ }^{5,14}$. In the conditions of the handle and the milking, parameters such as the suction reflex, the shape of the handle, the suction rhythm, the force used and the swallowing were evaluated, because difficulties in the handle can generate fissures and disruption in the nipple ${ }^{7}$.

Physical skin-to-skin contact, for example, has been stimulated primarily by the Kangaroo Method technique. This practice is related to the establishment of union ties between mother and child ${ }^{7}$. The communication of the mother with the baby, including the signs of bonding and affective bonds, are described in the literature as essential for an adequate moment of breastfeeding. Also, it is known that difficulties in establishing the link can make the process difficult, even postponing hospital discharge ${ }^{7}$. Visual contact is also part of the bonding process and is reinforced by the literature, since it is essential for a harmonious interaction between the mother and the baby during breastfeeding ${ }^{7}$. How to hold the baby, also considering the comfort of the mother, how to hold the breast and the position of the newborn are aspects that should be considered in the evaluation. The positioning of the NB facilitates the attachment, provides better mother/baby interaction, and prevents the milk from being directed to the auditory tube, posing a risk of diseases in the middle ear, such as repetitive otitis ${ }^{5,7}$. Dysfunctions of oral motor skills, as well as incorrect handling, can lead to interference in breastfeeding, increasing the difficulties for breast milking to be effective, compromising breastfeeding efficiency. Observing the proper movement of the facial and oral musculature is essential for evaluation, since these aspects are important so that the baby can extract the necessary amount of milk, avoiding trauma and lesions in the breasts ${ }^{16}$.

Regarding the morphology of the orofacial and suction motor system, it is worth mentioning that aspects in this line were evaluated in three of the instruments included in the present review (Protocol for the Evaluation of Breastfeeding of the Preterm Newborn/ Speech Therapy Assessment Form of breastfeeding, Observation protocol and breastfeeding evaluation, Protocols for evaluation and speech therapy following) $5,6,13-15$. These instruments scored conditions of the handle (chin position, oral opening, lip sealing, complete handle of the areola) and milking conditions (jaw movement, cheeks, rhythm and suction force and tongue movement) ${ }^{5,6,13-15}$. It is emphasized that breastfeeding also has a positive effect on the growth and development of the stomatognathic system. When sucking, the baby places the tongue in the correct position within the oral cavity, the arches, cheeks and tongue move harmoniously and the whole neuromuscular function of the mouth develops in a balanced way ${ }^{17}$. Any alteration in the orofacial structures can result in imbalance and breastfeeding offers the baby adequate bone and muscular development ${ }^{17}$.

Finally, it is important to note that breastfeeding is not only a natural form of feeding for the newborn, but also a safer form of feeding ${ }^{16}$. It is expected that the NB adequately performs the functions of respiration, suction and deglutition, basic for the good performance of breastfeeding. However, in the preterm newborn (PTNB), these functions may not be well established, hindering the whole process of breastfeeding. It is justifiable the need to verify the breastfeeding conditions of the PTNB, in order to identify factors unfavorable to the success of exclusive breastfeeding, and with this, to intervene early in the possible difficulties of this population. The promotion of breastfeeding should be started even during the gestational period, during 
prenatal care. It is an opportune moment to help pregnant women with their doubts and concerns.

Regarding the breastfeeding process, there are other factors that may interfere positively or negatively with their success and that were not included in the instruments considered in the present review. Among them, we can consider the conditions of birth of the baby, postpartum period and habitual conditions of life. Consideration should also be given to the influence of the type of delivery and the initiation of lactation, with vaginal delivery being the most effective in establishing lactation. In natural childbirth, contact between mother and child occurs earlier in relation to cesarean section, in the immediate postpartum period, newborns are more apt to initiate breastfeeding ${ }^{17-19}$. In addition, the difficulty of mothers in breastfeeding should be noticed $^{15}$.

In addition to the need to include the points mentioned above in the evaluation protocols, there is a need for greater effort in the search for evidence of validity of the instruments to be used in clinical and research practices. It was observed, in this review, that there is no validation of most of the protocols identified and it is important to emphasize that translations and adaptations of instruments require cross-cultural validation for later clinical validation. As limitations, it is observed that included studies were developed with a reduced number of subjects, a factor that hinders the generalization of the results presented.

\section{CONCLUSION}

Based on the results found in the present review, the studies produced by Speech Therapy with standardized and validated protocols for breastfeeding evaluation are scarce. The major focus is on the assessment of preterm infants leaving a gap in the assessment of breastfeeding in term babies. It is suggested that further studies be conducted, especially with a focus on validating instruments.

\section{REFERENCES}

1. Bueno KCVN, Gomez RS. A importância do aleitamento materno exclusivo até os seis meses de idade para a promoção de saúde da mãe e do bebê [trabalho de conclusão de curso]. Campos Gerais (MG): Universidade Federal de Minas Gerais/NESCON; 2013.

2. World Health Organization. Department of Nutrition for Health and Development. Department of
Child and Adolescent Health and Development. The optimal duration of exclusive breastfeeding: report of an expert consultation. [cited 2018 Aug 22]. Available from:http://www.who.int/nutrition/ publications/optimal_duration_of_exc_bfeeding_ report_eng.pdf

3. Brasil. Ministério da Saúde. Secretaria de Atenção à Saúde. Departamento de Ações Programáticas e Estratégicas. II Pesquisa de prevalência de aleitamento materno nas capitais brasileiras e Distrito Federal. 1a edição. Brasília: Ministério da Saúde; 2009.

4. Delgado SE, Halpern R. Amamentação de prematuros com menos de 1500 gramas: funcionamento motor-oral e apego. Pró-Fono $\mathrm{R}$ Atual. Cient. 2005;17(2):141-52.

5. Castelli CTR, Almeida ST. Evaluation of orofacial characteristics and breastfeeding in preterm newborns before hospital discharge. Rev. CEFAC. 2015;17(6):1900-8.

6. Scheeren B, Mengue APM, Devincenzi BS, Barbosa LR, Gomes E. Condições iniciais no aleitamento materno de recém-nascidos prematuros. Rev Soc Bras Fonoaudiol. 2012;24(3):199-204.

7. Delgado SE, Zorzetto M. A amamentação de bebês pré-termo: um caminho possível para a construção da comunicação. Rev Bras Cresc Desenv Hum. 2003;13(1):63-72.

8. Ministério da Saúde. Secretaria de Atenção à Saúde. Departamento de Ações Programáticas Estratégicas. Bases para a discussão da Política Nacional de Promoção, Proteção e Apoio ao Aleitamento Materno. [cited 2018 Aug 22]. Available from: http://bvsms.saude.gov.br/bvs/publicacoes/ bases_discussao_politica_aleitamento_materno. pdf

9. Sanches MTC, Buccini GS, Gimeno SGA, Rosa TEC, Bonamigo AW. Fatores associados à interrupção do aleitamento materno exclusivo de lactentes nascidos com baixo peso assistidos na atenção básica. Cad Saúde Pública. 2011;27(5):953-65.

10. Sistema de Conselhos Federal e Regionais de Fonoaudiologia. Contribuição da Fonoaudiologia para o avanço do SUS. [cited 2018 Aug 13]. Available from: http://epsm.nescon.medicina.ufmg. br/dialogo09/Biblioteca/Artigos/Contribuicao_ Fonoaudiologia_Avanco_SUS.pdf

11. Fussiger CC, Oliveira S. A inserção do profissional de fonoaudiologia no SUS - Relatório de experiência no município de São Vendelino-RS 
[trabalho de conclusão de curso]. Porto Alegre (RS): Universidade Federal do Rio Grande do Sul; 2012.

12. Sartorio BT, Coca KP, Marcacine KO, Abuchaim ESV, Abrão ACFV. Instrumentos de avaliação do aleitamento materno e seu uso na prática clínica. Rev Gaúcha Enferm. [online]. 2017 [cited 2018 Aug 22];38(1):e64675. Available from: http://www.scielo.br/pdf/rgenf/v38n1/0102-6933rgenf-1983-144720170164675.pdf

13. Medeiros AMC, Bernardi AT. Alimentação do recém-nascido pré-termo: aleitamento materno, copo e mamadeira. Rev Soc Bras Fonoaudiol. 2011;16(1):73-9.

14. Silva PK, Almeida ST. Evaluation of preterm infants during the first offering of the maternal breastfeeding in a neonatal intensive care unit. Rev. CEFAC. 2015;17(3):927-35.

15. Mosele PG, Santos JF, Godói VC, Costa FM, Toni PM, Fujinaga $\mathrm{Cl}$. Assessment scale of newborn sucking for breastfeeding. Rev. CEFAC. 2014;16(5):1548-57.

16. Melo AM, Osório MM. Avaliação da mamada em recém-nascidos prematuros [dissertação]. Recife (PE): Universidade Federal de Pernambuco; 2008.

17. Bervian J, Fontana M, Caus B. Relação entre amamentação, desenvolvimento motor bucal e hábitos bucais - revisão de literatura. RFO UPF. 2008;13(2):76-81.

18. Faleiros FTV, Trezza EMC, Carandina L. Aleitamento materno: fatores de influência na sua decisão e duração. Rev Nutr. 2006;19(5):623-30.

19. Fujinaga $\mathrm{Cl}$, Chaves JC, Karkow IK, Klossowski $\mathrm{DG}$, Silva FR, Rodrigues AH. Lingual frenum and breast feeding: descriptive study. Audiol, Commun Res. [online]. 2017 [cited 2018 Aug 22];22:e1762. Available from: http://www.scielo.br/pdf/acr/ v22/2317-6431-acr-2317-6431-2016-1762.pdf 